\title{
Innovation Drivers in the Cypriot Food and Beverage Industry
}

\author{
Efstathiades A.**, Boustras G. ${ }^{\dagger}$, Bratskas R. ${ }^{\dagger}$ and Michaelides A. ${ }^{\dagger}$ \\ ${ }^{\ddagger}$ European University Cyprus, 6, Diogenes Str., Engomi, 2404 Nicosia, Cyprus, ${ }^{\dagger}$ RTD Talos Ltd, PO Box 21722, 1512 \\ Nicosia, Cyprus
}

\begin{abstract}
The Food and Beverage industry, a leading sector of the Cypriot manufacturing industry is under investigation in our study. The influence of innovation as a development vehicle is considered and factors affecting it have been investigated. In order to define and introduce these factors affecting innovation in the Cypriot manufacturing sector a nationwide survey is carried out. All five prefectures (Nicosia, Ammochostos, Limasol, Larnaca and Paphos) are covered and a sample of $5 \%$ of the whole Food and Beverage sector is surveyed. A closed questionnaire, made of five sections is used in order to collect information that will be used in a second stage in order to introduce the innovation factors affecting industrial development.

The results illustrate the gradual adoption of a pro-innovation culture in the Cypriot Food and Beverage Industry. Among others it was shown, that companies that have proceeded with product innovation, process innovation and organizational innovation have experienced the impact of innovation on their organizational performance.
\end{abstract}

\section{BACKGROUND INFORMATION}

Innovation itself is very broad concept and, as a result, various classifications of innovation have been developed and applied in the literature. Most researchers have focused on technology-related innovations, such as the introduction of products that requirees radical changes in the production process. The concept of innovation however can be seen extending far beyond radical and technology- based product innovation.

The European Union's Green Paper on Innovation, suggests that there are three forms of innovation - Product, process and organization.

Innovation Is

a) The renewal and enlargement of the range of products and services and the associated markets

b) The establishment of new methods of production, supply and distribution and

c) The introduction of changes in management, work organization, and the working conditions and skills of the workforce.

Organizational innovation deals with changes in marketing, purchases and sales, administration, management and staff policy. Organizational innovation has gained importance in all manufacturing sectors and especially in the Food and beverage sector through the implementation of ISO 9000 and other health safety and quality standards [1-3].

Innovative organizations embrace innovation by constantly introducing change. Innovations include:

- New work structures (teams, networks, outsourcing, and creating value webs new work procedures)

"Address correspondence to this author at the European University Cyprus, 6, Diogenes Str., Engomi, 2404 Nicosia, Cyprus; Tel: +357 22713 000; Fax: +357 22664 531; E-mail: a.efstathiades@euc.ac.cy
- Advanced technology, new manufacturing methods, information technology, quality management and process cycle time, human resource management strategies to ensure strategic fit with the business goals and inject flexibility (constant training, recruiting the best talent and rewarding employees, creating a work environment to spur innovation)

- Encourage risk taking behaviours and valuing experimentation [4]

Researchers and managers have tried various approaches to clarifying the relationship between organizational characteristics and the adoption of innovation in the face of multiple dimensions of innovation.

Hitt et al. [5] combined the acquisition of process innovations with the adoption of product innovations and market innovations into a single variable termed external innovation. When using their approach they did not find significant relationship between firm size and the adoption of external innovation. Others [6] found a significant relationship between firm size and product innovation, and others [7] between firm size and process innovation.

Terziovski [4] presenting the results of a major study commissioned by the Australian Manufacturing Council [8], mentions on the basis of a 1,300 response data base, that continues improvement and innovation management which have a positive impact on the business performance of individual firms.

Francisco et al. [9] in their study regarding the possible relationship between perceptions of Quality and innovation environments at Bank branches (80 bank offices) presents the relationship between TQM approaches and Innovation.

Customer orientation is found to be a stimulus for innovation in an organization, This provides a clear orientation to innovation, as it links innovation to customer needs, while continuous improvement promotes change, innovation and creativity, as it reflects on how the work is organized and 
managed. On the other hand customer orientation may prevent organizations from undertaking radical innovations while overemphasis on efficiency of continuous improvement may ultimately minimize and even remove availability of the resources required for innovation.

Empowerment makes people feel that they have a certain degree of autonomy, which makes their work more innovating. Teamwork is one of the most effective communication channels, and communication is one of the main determinants for innovation within organizations. On the other hand the cultural trend to teamwork is detrimental to radical innovation and inventions.

Tucker [10] put forward four essential principles of managing innovation in the new century which are connected to the comprehension of a company's approach to innovation, the organized and systematic structure of innovation's implementation, the level of entire organization involvement in the innovation process and the favourable climate for innovation inside a company.

A framework proposed by Neely et al. [11] suggests that the firm's capacity to innovate and innovation itself does not depend upon a company's resources and internal environment, but also on external facilitating factors (business support agencies, public grants, active local business networks etc.) which tend to be different in different contexts. In detail the proposed framework is based on the following assumptions:

1. A firm possesses an inherent capacity to innovate, which is embedded in the firm's culture, internal processes and capabilities to understand the external environment.

2. The capacity to innovate the firm affects the innovativeness of the firm in terms of product and process innovation, and as well as organizational innovation.

3. Even if a firm is highly innovative, it has to exploit its innovations in terms of outcomes - i.e. use them to reduce costs and/or to offer products or services to its customers. This is a condition to gain better business performance, such as market share and financial performance.

The external contextual environment can influence both the firm's capacity to innovate.

On the other hand the following factors are identified as factors inhibiting innovation:

- Innovation is poorly defined because customer requirements are not well understood and therefore the goals are not established properly. This is often because some organizations tend to be internally focused and innovating activity is weighted in terms of economic returns and short- term goals such as profit improvement targets.

- Culture is too inhibitive and as such does not foster innovation as an ongoing activity. Employees are not fully aware of the need to be proactive and innovate, and not necessarily encouraged and motivated to perform using their creative potential. There is lack of involvement, absence of team work, and the thinking that innovation is a management responsibility.

- Organizational factors such as attitudes of doing more of the same, rewarding the status quo, poor resource allocation and utilization.

Innovation has always been at the centrepiece of competitiveness. Competitiveness comes from innovative minds. The lesson is clear. To remain on top you have to produce the consumer products that people need. You have to find and convert new innovations into producible goods. You have to continously try to develop useful applications from what many would consider useless by- products.

A company embarks on innovation projects in order to improve its position in the competitive arena. The competitive success can be measured in terms of improvements in different business performances, such as R.O.I, market share and so on [12].

There are cases in which innovation does not lead to positive effects on business performance. It is not sufficient to introduce the innovation, but in order to gain better business performance, the innovation has to produce effective outcomes [13-14].

These can be obtained by leveraging technological innovation, information and communication technology, and organizational changes [15-16].

According to Efstathiades et al. [17] technology can only contribute to a competitive success if it is integrated into organizations' business strategies and practices.

A model proposed by Neely et al. [11] uses five constructs relating innovation performance and innovation practices as follows: business performance, outcomes of innovation, innovation, capacity to innovate and external contextual environment.

The dimensions of company performance that can be influenced by the outcomes of innovation are:

- Return on Investment

- Market share

- Competitive position versus direct competitors

- Value to customers (the extend to which product and services are seen by customers as value for money)

\section{METHODOLOGY}

Innovation and the ability of Cypriot SMEs to adapt to new entrepreneurial challenges is the central theme of a larger project the research team is currently running.

As mentioned above the aim of this study is to identify and introduce a list of factors affecting innovation in Cyprus. The chosen method to collect information was decided to be that of a closed questionnaire and a carefully selected sample of food and beverage manufacturing companies in Cyprus were chosen for the purposes of this study.

The first section concentrates on collecting general information used to categorize the companies. The second section focuses on the degree to which companies have introduced innovation to their processes, products and internal 
training. The third section maps the external relation of the companies with innovation providers and trend setters by assigning values to parameters affecting their processes and personnel. The fourth section maps the factors delaying the introduction of innovation in processes, products and internal training by measuring the economic, entrepreneurial and other reasons affecting it. Finally the fifth section investigates the relation of innovation (if any) to industrial and entrepreneurial development.

As a part of a larger survey carried out in Cyprus, data collected so far is presented on this paper. The survey has taken place and results have been received and analyzed. The survey is a part of larger project dealing with innovation in the Cyprus Food and Beverage Industry and it is funded by the Cyprus Research Promotion Foundation.

\section{RESEARCH AIM AND OBJECTIVES}

The aim of this paper is to investigate the degree of innovation in the Cyprus manufacturing industry and to examine how these expectations are formed and how their achievement is assessed. In detail the objectives of this paper are:

- To examine the extend of innovation level in the Cyprus Food and Beverage Industry

- To identify the main factors that determine the decision of companies to adopt or not innovate strategies

- To investigate the main inhibitors of the innovation process

- To examine the innovation implementation process with emphasis to the extent of the application of strategic management activities/practices leading to innovation performance

- To identify the impact of the innovation process at the organizational Performance

- To identify specific organizational factors (through factor analysis) that foster the innovation process.

\section{SAMPLE CHARACTERISTICS}

The size of the sample includes 50 Cypriot manufacturing enterprizes $(\sim 5 \%$ of the total size of manufacturing enterprizes, in the Food and Beverage sector in Cyprus). The survey took place using a questionnaire which is constituted by short and explicit questions which allow the export of as much qualitative as quantitative outcomes for the level of growth of innovation in the Cypriot manufacturing enterprizes.

At a next stage the survey data were coded and logged in SPSS to allow statistical experimentation. Advanced statistical techniques such as factor analysis are used to critically analyze the questionnaire output and derive at empirical models.

Table 1. Geographic Representation of the Sample Companies

\begin{tabular}{|c|c|c|c|c|c|}
\hline & LIMASOL & NICOSIA & LARNAKA & PAPHOS & Total \\
\hline Nr. & 19 & 14 & 12 & 5 & 50 \\
\hline
\end{tabular}

The geographic representation and the employment characteristics of the sample are shown in Tables $\mathbf{1}$ and $\mathbf{2}$ below.
Table 2. Employment Characteristics of Sample Companies

\begin{tabular}{|c|c|c|}
\hline Employment & Number of Enterprises & Number of Workers \\
\hline \hline $1-25$ & 33 & 432 \\
\hline $26-50$ & 10 & 344 \\
\hline $51-75$ & 3 & 170 \\
\hline $76-100$ & 2 & 195 \\
\hline $100>$ & 2 & 455 \\
\hline Total & 50 & 1596 \\
\hline
\end{tabular}

Out of 50 enterprises, 19 of them reside in the Limasol, 14 of them in Nicosia, 12 in Larnaka and 5 in Paphos (Table 1). Employment in the 50 enterprizes of sample, count up about 1596 workers which are approximately $2 \%$ of the total workforce occupied in the Manufacturing Industry in Cyprus (Statistical Service of Cyprus).

In this survey sample, 15 enterprises fall under the sector of Confectioneries-bakery, 4 enterprises in the sector of Dairy Products, 5 enterprises in the sector of Ready to cook and Frozen foods, 4 enterprises in the sector of Marketing of Food Products-Import and 2 enterprises in the Beverage Sector.

The turnover of these 50 enterprises is above 80 million Cypriot pounds.

\section{ANALYSIS OF RESULTS}

\section{The Innovation Process}

One of the objectives of this paper is to examine the extent of the level of innovation in the Cypriot Food and Beverage Industry. This is examined by close investigation of the levels of innovation as follows:

(a) degree of product innovation,

(b) degree of process innovation,

(c) degree of organizational innovation,

(d) degree of management activities - practices leading to innovation performance.

Results relevant to the degree which Cypriot companies have introduced product innovation are shown in Table $\mathbf{3}$ below.

Table 3. Degree of Product Innovation

\begin{tabular}{|c|c|c|c|}
\hline & $\mathbf{N}$ & Mean & S.D \\
\hline \hline $\begin{array}{c}\text { New or drastically improved } \\
\text { product }\end{array}$ & 50 & 7.33 & 2.557 \\
\hline Qualitative change of product & 50 & 7.54 & 2.354 \\
\hline Substitution of outdated products & 50 & 6.2 & 2.956 \\
\hline $\begin{array}{c}\text { Expansion of produce outside the } \\
\text { main frame of production }\end{array}$ & 50 & 6.53 & 2.501 \\
\hline $\begin{array}{c}\text { Development of environmentally } \\
\text { friendly products }\end{array}$ & 50 & 6.54 & 2.706 \\
\hline
\end{tabular}


Results reveal that product innovation is used in a considerable extent in the Cypriot Manufacturing Industry (food and beverage sector).

The most popular activities considered for product innovation were: "New Drastically Improved Product" as well as "Product Differentiation". Important steps were also made in "Product Expansion" and the "Development of Environmentally Friendly products". Companies do proceed with Product innovation reflecting changes in the existing products and services produced.

The level of innovation introduced in the production process in the Cypriot Manufacturing Industry (foods and drinks) is illustrated in Table 4.

Table 4. Degree of Process Innovation

\begin{tabular}{|c|c|c|c|}
\hline & $\mathbf{N}$ & Mean & S.D \\
\hline \hline $\begin{array}{c}\text { New techniques and process of } \\
\text { production }\end{array}$ & 50 & 7.26 & 2.113 \\
\hline Integration of advanced technology & 50 & 7.48 & 1.963 \\
\hline Introduction of IT & 50 & 6.75 & 2.422 \\
\hline Process quality systems & 50 & 7.91 & 1.86 \\
\hline $\begin{array}{c}\text { New material and technical support } \\
\text { processes }\end{array}$ & 50 & 6.55 & 2.556 \\
\hline New methods of product delivery & 50 & 7.36 & 2.207 \\
\hline New inflow distribution methods & 50 & 6.71 & 2.074 \\
\hline
\end{tabular}

New quality systems, technological upgrading, new methods of product delivery, new techniques and new processes of production were indicated as the most important process innovation outcome.

In terms of organizational innovation and the results presented in Table $\mathbf{5}$ one can conclude the following. The top driver for organizational innovation was the improvement of staff's skills with the improvement of suppliers, performance coming second and the changes on organizational structure coming third. Interesting finding is that companies did not consider organizational innovation towards reducing the staff that is not directly related with the Production Process.

Table 5. Degree of Organizational Innovation

\begin{tabular}{|c|c|c|c|}
\hline & N & Mean & S.D \\
\hline \hline Organizational Changes & 50 & 6.96 & 2.097 \\
\hline Advanced Management & 50 & 6.58 & 2.2 \\
\hline Business Process Reengineering & 50 & 6.02 & 2.554 \\
\hline Focus on Sales and Marketing & 50 & 6.82 & 2.092 \\
\hline $\begin{array}{c}\text { Improvement of staff's skills } \\
\text { Improvement of suppliers per- } \\
\text { formance }\end{array}$ & 50 & 7.28 & 2.029 \\
\hline $\begin{array}{c}\text { Reduction of staff not directly } \\
\text { related with the production process }\end{array}$ & 50 & 4.62 & 2.733 \\
\hline
\end{tabular}

Management activities lead to innovation performance and results are presented in Table 6.

These results reveal the high level of importance given to the strategic role of Top Management in identifying the direction, the right distribution of roles and the active involvement in planning and evaluation of innovative processes.

Emphasis is given in the focusing and planning based on customer's needs, the introduction of appropriate processes of planning and control in their production line. An interesting paradox identified was the tendency of exterior orientation of the enterprises and their effective ability of building relations with all external points of contact -suppliers, distributors which come in contrast to the fact that connection with external know-how providers is not used in great extent.

Furthermore, the internal environment is enforced by focusing (i) on the staff's contribution, team work, and clear identification of operational aims, (ii) on the degree of liberty to act and risk taking freedom given to staff to define and execute their duties and (iii) on seriously emphasizing on awards and rewards which is the way successes and failures are dealt with and are rewarded constructing an autonomous and flexible organizational structure.

\section{FACTORS INHIBITING THE INNOVATION PROC- ESS}

The main inhibitors of the innovation process in the Cypriot Manufacturing Industry (sector of foods and drinks) are measured by examination of:

- Economic inhibitors parameters

- Organizational inhibitors parameters

- Other inhibitors parameters (other)

and are shown in Tables 7, 8 and $\mathbf{9 .}$

As to the factors hindering the innovation process related to economic inhibitors, results coming from Table 7 suggest that the excessively high cost and the long period of depreciation were the most important inhibiting factors, followed by the non existence and the lack of suitable funding sources and the high risk that surrounds the innovation process.

There is lack of involvement, absence of team work, and the perception that innovation is a management responsibility. In a great extent the same result came out from this study (as shown in Table 8), where the absence of skilled staff and the inadequate innovation capacity were the most important inhibitors. Also the absence of co-operation opportunities and team work and the insufficient information/knowledge on market reflect the inhibiting role of the internally focused factor of these enterprises. Previous research suggests that the factor of culture is a very important inhibiting factor and as such does not foster innovation as an ongoing activity. Employees are not fully aware of the need to be proactive and innovative, and not necessarily encouraged and motivated to perform using their creative potential [15].

Other factors delaying the introduction of innovation are illustrated in Table 9. Based on the mean value of those parameters, legislation, norms, regulations, standards and taxation proved to be the most obstructing parameters, followed 
Table 6. Degree of Management Activities - Practices Leading to Innovation Performance

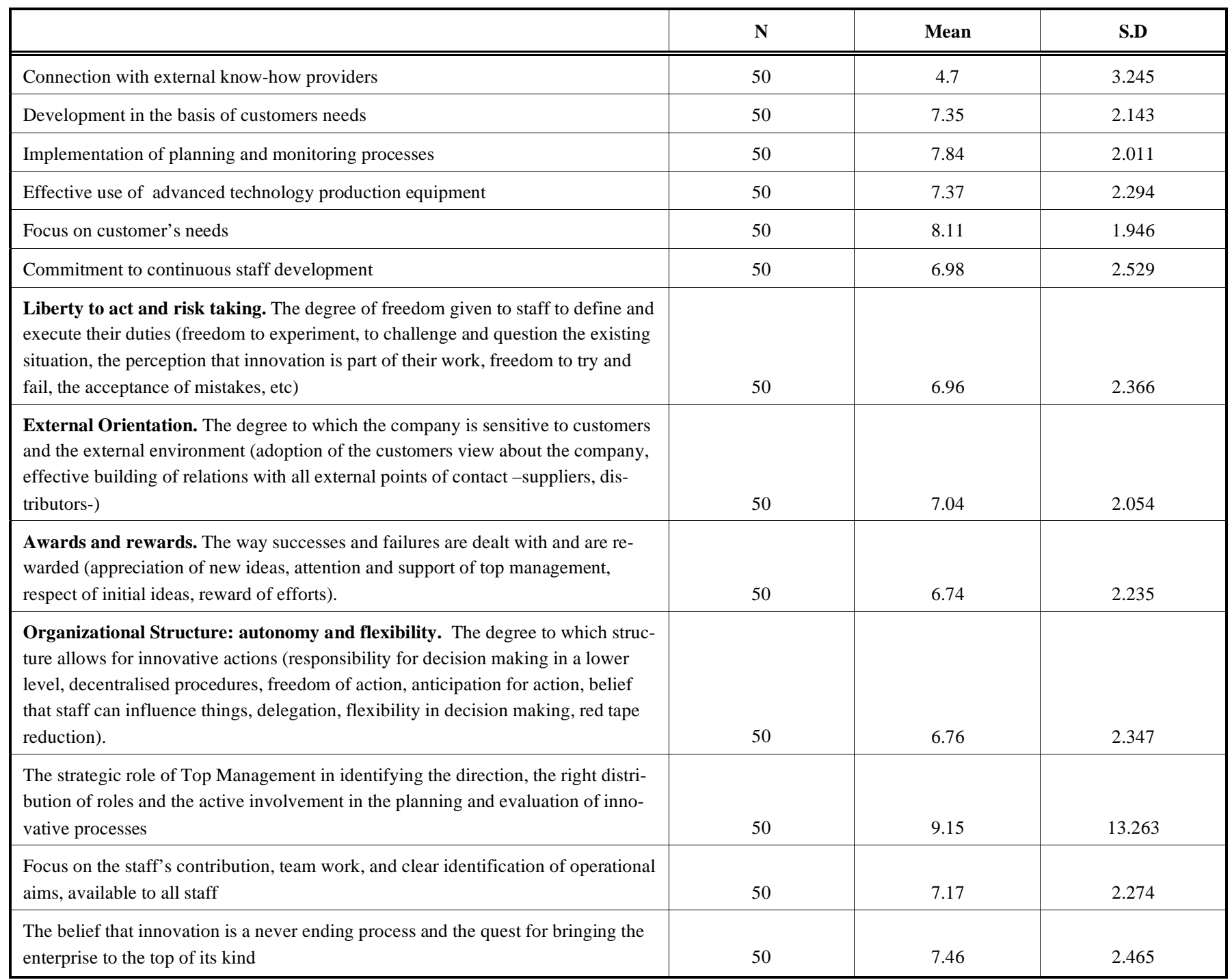

Table 7. Economic Inhibitor Parameters

\begin{tabular}{|c|c|c|c|}
\hline & N & Mean & S.D \\
\hline \hline Identification of high risk & 50 & 6.2 & 2.4 \\
\hline Too costly & 50 & 7.43 & 2.007 \\
\hline Non existence of funding sources & 50 & 6.39 & 2.49 \\
\hline Long period of depreciation & 50 & 6.59 & 2.207 \\
\hline
\end{tabular}

by the absence of opportunities for the development of new technologies and low customer response to the new products and processes.

\section{INNOVATION AND ORGANIZATIONAL PER- FORMANCE}

One of the main objectives of the study is to examine the impact of innovative activities on organizational performance. The results in Table $\mathbf{1 0}$ reveal that delivery times, the ability of the companies to satisfy customer needs is highly
Table 8. Organizational Inhibitor Parameters

\begin{tabular}{|c|c|c|c|}
\hline & N & Mean & S.D \\
\hline \hline Inadequate innovation capacity & 50 & 5.98 & 2.696 \\
\hline Absence of skilled staff & 50 & 6.15 & 2.724 \\
\hline Insufficient knowledge on high tech issues & 50 & 5.41 & 2.344 \\
\hline Insufficient knowledge of the market & 50 & 4.98 & 2.427 \\
\hline Absence of innovation cost monitoring & 50 & 5.47 & 2.519 \\
\hline Internal resistance to change & 50 & 4.8 & 2.539 \\
\hline Insufficient third party services & 50 & 5.09 & 2.698 \\
\hline Absence of co-operation opportunities & 50 & 5.46 & 2.73 \\
\hline
\end{tabular}

impacted and is important for the outcome of the company's innovative activities.

"Volume Flexibility" and "Quality" as the winning criteria are proven to be influenced also positively. Most of the 
Table 9. Inhibitor Parameters

\begin{tabular}{|c|c|c|c|}
\hline & $\mathbf{N}$ & Mean & S.D \\
\hline $\begin{array}{l}\text { Absence of opportunities for the devel- } \\
\text { opment of new technology }\end{array}$ & 50 & 5.28 & 2.57 \\
\hline Absence of infrastructure & 50 & 5.13 & 2.482 \\
\hline $\begin{array}{l}\text { No need for innovation, because of previ- } \\
\text { ously introduced innovations }\end{array}$ & 50 & 4.54 & 2.553 \\
\hline Deficiencies of IPR legislation & 50 & 5.04 & 2.875 \\
\hline Legislation, norms, standards, taxation & 50 & 5.72 & 1.946 \\
\hline $\begin{array}{l}\text { Low customer response to the new prod- } \\
\text { ucts and processes }\end{array}$ & 50 & 5.17 & 2.541 \\
\hline
\end{tabular}

Table 10. Innovation and Organizational Performance

\begin{tabular}{|c|c|c|c|}
\hline & N & Mean & S.D \\
\hline \hline Market share maintenance & 50 & 7.22 & 2.149 \\
\hline Market share increase & 50 & 7.17 & 2.274 \\
\hline Entry to new markets or new target-groups & 50 & 6.35 & 2.806 \\
\hline Price & 50 & 6.89 & 1.945 \\
\hline Quality consistency & 50 & 7.78 & 2.299 \\
\hline Absolute quality & 50 & 7.22 & 2.513 \\
\hline Production volume flexibility & 50 & 7.63 & 2.122 \\
\hline Customer need satisfaction flexibility & 50 & 7.83 & 2.204 \\
\hline Ability to deliver inside the promised time & 50 & 8 & 2.355 \\
\hline Return on investment (R.O.I) & 50 & 5.9 & 2.332 \\
\hline Decrease of labour cost per product unit & 50 & 5.71 & 2.361 \\
\hline $\begin{array}{c}\text { Decrease of material - energy cost per } \\
\text { product unit }\end{array}$ & 50 & 5.89 & 2.238 \\
\hline $\begin{array}{c}\text { Decrease of environmental consequences } \\
\text { or improved personnel H\&S }\end{array}$ & 50 & 6.76 & 2.207 \\
\hline $\begin{array}{c}\text { Decrease of customer response time } \\
\text { Improved personnel satisfaction }\end{array}$ & 50 & 6.89 & 2.56 \\
\hline $\begin{array}{c}\text { Decreased personnel turnover } \\
\text { Dif }\end{array}$ & 50 & 6.45 & 2.357 \\
\hline
\end{tabular}

companies managed to maintain their market share, while some of them managed to increase it.

In conclusion, it is obvious that innovation has a positive impact on "satisfaction of customer needs" and "quality consistency" closely followed by "market share increase", "the decrease of environmental consequences or improved personnel H\&S", "the reduction employee's turnover", "the entry to new markets or new target-groups".

\section{IDENTIFICATION OF MANAGEMENT FACTORS THAT FOSTER THE INNOVATION PROCESS (FAC- TOR ANALYSIS)}

The sample of the companies under investigation was subjected to statistical analysis, aiming to modelling the innovation indicators and the identification of specific organi- zational factors that foster the innovation process in Cyprus by empirical means.

The first step of this modelling process entailed the analysis of the survey data by the means of factor analysis aiming to the development of a dimensional structure. The rationale of this methodological decision is twofold. First, a dimensional structure of innovation indicators was developed for the F\&B industry of Cyprus, and secondly, the extracted dimensions were treated as independent variables at the subsequent stages of the modelling process.

By examining the factor analysis results the factors that were extracted are tabulated in Tables 12, 13, 14, 15:

1. Factor 1: Level of existence of Strategic Management Practices and Decisions

2. Factor 2: Level of Operational relations, Company strategy and capacity utilisation related to final goals

3. Factor 3: Level of Organizational reaction to exterior environment influence

4. Factor 4: Level of Organizational and Structural orientation

5. Factor 5: Level of the dynamism of internal structure and the capability of the production process.

Similar work is done by [19] indicating the fundamental dimensions of organizational innovativeness being:

(a) The technological innovation challenges

(b) The manifested strategic innovation intentions

(c) The product innovativeness

(d) The innovativeness of core machinery and

(e) Innovative leadership

The above five-factor solution, account for $72.69 \%$ of the total variance, with $49.50 \%, 9.30 \%$, and $5.10 \% .4 .72 \%$ and $3.67 \%$ of the variance accounted by each factor respectively. The percentage of variance is shown in Table $\mathbf{1 1}$.

Table 11. Eigenvalues and Variance Explained of Survey Data

\begin{tabular}{|c|c|c|c|}
\hline \multirow{2}{*}{ Factor } & Eigenvalue & \multicolumn{3}{|c|}{ Percentage of Variance (\%) } \\
\cline { 2 - 4 } & \multicolumn{3}{|c|}{$\begin{array}{c}\text { Cumulative } \\
\text { percentage }\end{array}$} \\
\hline \hline 1 & 27.441 & 49.502 & 49.894 \\
\hline 2 & 5.118 & 9.306 & 59.200 \\
\hline 3 & 2.806 & 5.101 & 64.301 \\
\hline 4 & 2.596 & 4.720 & 69.021 \\
\hline 5 & 2.020 & 3.673 & 72.694 \\
\hline
\end{tabular}

The extracted factor solution can be considered as satisfactory. As Hair et al. [20] suggested, in social sciences that percentages around $60 \%$ of the total variance are considered as satisfactory. 
Table 12. Factor 1. Level of existence of Strategic Management Practices and Decisions

\begin{tabular}{|c|c|}
\hline Rotated Component Matrix (a) & $\begin{array}{l}\text { Component } \\
\text { (1) }\end{array}$ \\
\hline $\begin{array}{l}\text { G48- The importance given to systems for the effective } \\
\text { management of innovation: systems are important for } \\
\text { the correct aiming and production management }\end{array}$ & .911 \\
\hline $\begin{array}{l}\text { G46- Management of activities is not left on individu- } \\
\text { als but it is guided through the constructive involve- } \\
\text { ment of all departments of the company. }\end{array}$ & .899 \\
\hline G45- The effective use of all the staff's skills available & .894 \\
\hline $\begin{array}{l}\text { G44- Management of activities driven by the thorough } \\
\text { understanding of the customers needs the existence of } \\
\text { good practises and the nature of the company's aims }\end{array}$ & .880 \\
\hline $\begin{array}{l}\text { G47- The use of modern innovation management tools } \\
\text { and techniques }\end{array}$ & .878 \\
\hline $\begin{array}{l}\text { G51- The technical capacity and ability as well as the } \\
\text { right management of innovative programmes in order } \\
\text { to facilitate the delivery to customers }\end{array}$ & .862 \\
\hline $\begin{array}{l}\text { G54- Focus on the staff's contribution, team work, and } \\
\text { clear identification of operational aims, available to all } \\
\text { staff }\end{array}$ & .861 \\
\hline $\begin{array}{l}\text { G55- The belief that innovation is a never ending proc- } \\
\text { ess and the quest for bringing the enterprise to the top } \\
\text { of its kind. }\end{array}$ & .851 \\
\hline $\begin{array}{l}\text { G49- The existence of identification mechanisms and } \\
\text { deduction obstacles, giving the opportunity to pro- } \\
\text { gramme leaders / teams / managers to carry on with } \\
\text { their work }\end{array}$ & .843 \\
\hline $\begin{array}{l}\text { G39- Existence of innovation as a voluntary activity } \\
\text { especially where there is a stable belief that innovation } \\
\text { is important for the enterprise's competition }\end{array}$ & .841 \\
\hline $\begin{array}{l}\text { G34- Time for innovative actions and personal de- } \\
\text { velopment. The time and space given to employees to } \\
\text { develop new ideas and abilities and the way that new } \\
\text { ideas are adopted and implemented (capital, budget, } \\
\text { time, chances, tools infrastructure, personal develop- } \\
\text { ment, etc) }\end{array}$ & $\underline{.838}$ \\
\hline $\begin{array}{l}\text { G31- Myths and Legends. The degree to which suc- } \\
\text { cess stories are acknowledged and rewarded (symbolic } \\
\text { action, dissemination of success stories) }\end{array}$ & $\underline{.831}$ \\
\hline $\begin{array}{l}\text { G52- The management of innovation activity for the } \\
\text { on-time completion together with the careful choice of } \\
\text { the types of action that companies tend to get involved. }\end{array}$ & $\underline{.828}$ \\
\hline $\begin{array}{l}\text { G38- Development of the innovation process as an } \\
\text { integral part of corporate strategy }\end{array}$ & .827 \\
\hline
\end{tabular}

As has been previously discussed the "Level of existence of Strategic Management Practices and Decisions" is considered as a major factor to the innovative effort of the companies account for $49.5 \%$ of the variance.
This Strategic Management effort is focused on planning out and implementing the enterprise's strategy, which is a plan of implementation of innovation. Basic duties like (a) the definition of the mission of the enterprise, (b) the aim to include in the enterprise's mission concrete innovative objectives with effective and efficient concretisation and (c) the continuous evaluation of the implementation of the innovative process are shown to have serious prestige in Supplementary Managerial activities.

This is achieved by: (a) emphasizing on the provision of systems for effective management of the activity of innovation, (b) through an effective utilization of all personal skills that is in their disposal, (c) using the most modern tools and techniques guided always by a detailed knowledge of customer's needs and finally (d) with the contribution of all departments of enterprise.

Table 13. Factor 2. Level of Operational Relations, Company Strategy and Capacity Utilisation Related to Final Goals

\begin{tabular}{|l|c|}
\hline \multicolumn{1}{|c|}{ Rotate d Component Matrix(a) } & Component 2 \\
\hline \hline G12- Implementation of quality control practises & $\underline{\mathbf{. 7 9}}$ \\
\hline G11- Identification and quest for quality work & $\underline{\mathbf{8 2 7}}$ \\
\hline $\begin{array}{l}\text { G22- Dynamic and open minded company man- } \\
\text { agement }\end{array}$ & $\underline{\mathbf{. 7 7 8}}$ \\
\hline $\begin{array}{l}\text { G8- Implementation of planning and monitoring } \\
\text { processes }\end{array}$ & $\underline{\mathbf{. 6 9}}$ \\
\hline $\begin{array}{l}\text { G18- Provision of good after - sales customer } \\
\text { support }\end{array}$ & $\underline{\mathbf{. 7 5 5}}$ \\
\hline $\begin{array}{l}\text { G16- Focus on building effective customer rela- } \\
\text { tions }\end{array}$ & $\underline{\mathbf{. 7 5 1}}$ \\
\hline $\begin{array}{l}\text { G50- The importance of being proactive and have } \\
\text { the ability to realise real customer needs }\end{array}$ & $\underline{\mathbf{. 1 9}}$ \\
\hline $\begin{array}{l}\text { G25- Challenge and Commitment to action: the } \\
\text { degree of staff involvement in the everyday proc- } \\
\text { esses to the extent needed (focus on results, atten- } \\
\text { tion to detail, alertness to delivery times, attention } \\
\text { to project completion, appreciation of hard work, } \\
\text { red-tape reduction) }\end{array}$ & $\underline{\mathbf{. 6 3 0}}$ \\
\hline $\begin{array}{l}\text { G10- Periodical and constant evaluation of all } \\
\text { innovation processes }\end{array}$ & $\underline{\mathbf{. 5 2 8}}$ \\
\hline $\begin{array}{l}\text { G26- Liberty to act and risk taking. The degree } \\
\text { of freedom given to staff to define and execute their } \\
\text { duties (freedom to experiment, to challenge and } \\
\text { question the existing situation, the perception that } \\
\text { innovation is part of their work, freedom to try and } \\
\text { fail, the acceptance of mistakes, etc) }\end{array}$ & $\underline{\mathbf{. 6 3 0}}$ \\
\hline $\begin{array}{l}\text { G32- Leadership. The degree to which the man- } \\
\text { agement team illustrates its commitment to action } \\
\text { and leads by example (commitment of top man- } \\
\text { agement, implementation of the company's mission } \\
\text { statement). }\end{array}$ & $\begin{array}{l}\text { G21- Recruitment of the right associates (product } \\
\text { champions, technological gatekeepers etc) }\end{array}$ \\
\hline
\end{tabular}


Moreover importance is given on the contribution of personnel, the provision of the requested training, so as to develop new ideas and having in place a system that recognize and remunerate the achieved goals.

This study showed also that Strategic Management of Enterprises has acquired big importance lately in Cyprus because a lot of enterprises have focused on their growth and in the invasion and take-over of new markets.

The second factor that emerged from the variables that strengthen innovation is the "Level of Operational relations, Company strategy and capacity utilisation related to final goals" that accounts for $9.3 \%$ of the variance (Table 13).

The company strategy and organizational capacity utilization is focused on (a) the qualitative control practices, (b) the continuous requirement for effective and qualitative work, (c) the right administration of enterprise (Dynamic and open minded company management) and finally (d) the provision of good after - sales customer support.

Also the operational relations as part of the company's strategy are concerned with: (a) the building of right links and relations with the customers, (b) the degree of attendance of employees in the daily processes and their degree of involvement in the innovation process, (c) the degree of staff involvement in the everyday processes to the extent needed and the recruitment of the right associates. These factors are interconnected and correlated having as a result a more organized structure of enterprises concerned with the productive and innovative process and aiming at innovation as final product.

Finally, importance is given to the freedom of action and risk taking given to the staff in the determination and the execution of their duties (the freedom to experiment with new ways of production/service).

The third factor selected by the total of variables connected to innovation is: "Level of Organizational reaction to exterior environment influence" accounting for $5.1 \%$ of the variance (Table 14)

Table 14. Factor 3. Level of Organizational Reaction to Exterior Environment Influence

\begin{tabular}{|c|c|}
\hline Rotated Component Matrix(a) & Component 3 \\
\hline \hline G3- Willingness for the adoption of external "ideas" & $\underline{\mathbf{. 6 6 2}}$ \\
\hline G1- Connection with external know-how providers & $\underline{\mathbf{. 6 6 1}}$ \\
\hline $\begin{array}{c}\text { G5- Structural integration of innovation in the com- } \\
\text { pany departments }\end{array}$ & $\underline{\mathbf{. 6 6 0}}$ \\
\hline $\begin{array}{c}\text { G2- Internal and External communication with the } \\
\text { adoption of new communication channels }\end{array}$ & $\underline{\mathbf{. 6 3 9}}$ \\
\hline $\begin{array}{c}\text { G4- Handling of innovation as a corporate goal } \\
\text { G6- Involvement of all departments in the introduction } \\
\text { of innovation from the very first stages. }\end{array}$ & $\underline{\mathbf{. 5 5 1}}$ \\
\hline
\end{tabular}

Thus (a), the willingness for acceptance and adoption of exterior ideas (b), connection with external know-how pro- viders (c), the internal and external communication with the adoption of new communication channels and (d) involvement of all departments in the introduction of innovation from the very first stages are connected to the company's competitiveness. This in turn has to do with how the exterior environment affects the company.

Which are the management tools used by an enterprise, their policy responding to the variability of the interior and exterior environment and the means used in order to reach their goals through the innovation process, is explained by the fourth factor "Level of Organizational and Structural orientation" below (Table 15).

Table 15. Factor 4. Level of Organizational and Structural Orientation

\begin{tabular}{|c|c|}
\hline Rotated Component Matrix(a) & Component 4 \\
\hline \hline G14- Development of market oriented policies & $\underline{\mathbf{. 7 8 5}}$ \\
\hline $\begin{array}{c}\text { G28- External Orientation. The degree to which the } \\
\text { company is sensitive to customers and the external } \\
\text { environment (adoption of the customers view about } \\
\text { the company, effective building of relations with all } \\
\text { external points of contact -suppliers, distributors-) }\end{array}$ & $\underline{\mathbf{. 3 8}}$ \\
\hline G19- Provision of customer training & $\underline{\mathbf{5 3 5}}$ \\
\hline $\begin{array}{c}\text { G13- Effective use of advanced technology produc- } \\
\text { tion equipment }\end{array}$ & $\underline{\mathbf{. 9 6}}$ \\
\hline $\begin{array}{c}\text { G30- Structural interaction and. The degree to which } \\
\text { interaction between departments and processes is } \\
\text { encouraged and facilitated (staff movement between } \\
\text { different departments, team work, effective man- } \\
\text { agement of interaction, flexibility to work) }\end{array}$ & $\underline{\mathbf{. 3 9 8}}$ \\
\hline $\begin{array}{c}\text { G23- Ability to attract talented researchers and } \\
\text { managers }\end{array}$ & $\underline{\mathbf{. 2 4 4}}$ \\
\hline
\end{tabular}

Organizational and structural orientation is focused on the development of market oriented policies, the exterior orientation and the sensitiveness to the customers' needs, provision of customer training and the effective utilization of advanced technological production equipment.

In their effort to become more competitive companies focus on the degree to which interaction between departments and processes is encouraged and facilitated (staff movement between different departments, team work, effective management of interaction, flexibility to work) as well as the ability in the attracting of talent managers and researchers.

Factor 5: "Level of the dynamism of internal structure and the capability of the production process" accounts for $3.7 \%$ of the variance and puts a label on how strong are the relations between the departments in an enterprise, the resistance of the structure of enterprises, what way they try to maintain their market share and increase their enterprise dynamism through innovation process.

The ability in attracting talented and gifted managers and researchers is important, involvement of users / customers in the design and implementation of products and the focus in the needs of customers is given serious importance and therefore make the fifth factor. 
Table 16. Factor 5. Level of the Dynamism of Internal Structure and the Capability of the Production Process

\begin{tabular}{|c|c|}
\hline Rotated Component Matrix(a) & Component 5 \\
\hline \hline $\begin{array}{c}\text { G23- Ability to attract talented researchers and man- } \\
\text { agers }\end{array}$ & $\underline{\mathbf{. 6 5 8}}$ \\
\hline $\begin{array}{c}\text { G17- Involvement of users / customers in the design } \\
\text { and implementation of products }\end{array}$ & $\underline{\mathbf{6 3 2}}$ \\
\hline G15- Focus on customer's needs & $\underline{\mathbf{. 5 2}}$ \\
\hline $\begin{array}{c}\text { G24- Commitment to continuous staff development } \\
\text { G42- The existence of an inclusive type of Manage- } \\
\text { ment with open access to decision making. }\end{array}$ & $\underline{\mathbf{. 5 0 3}}$ \\
\hline
\end{tabular}

Finally, the commitment for the training and development of staff, the existence of an inclusive type of management with open access to decision making, play an important role in the dynamism of the base of the structure of enterprises.

\section{CONCLUSIONS}

A nationwide survey was carried out and so some of the important findings are presented in this paper. Results of this study reveal that innovation is introduced in a considerable extent, but still there is lot to be done in the Cypriot Food and Beverage Industry. Results indicate that companies do not innovate in a rather balanced way. The most popular activities considered for product innovation were: "New Drastically Improved Product" as well as "Product Differentiation". Important steps were also made in "Product Expansion" and the "Development of Environmentally Friendly products". Companies do proceed with Product innovation reflecting changes in the existing products and services produced.

The top driver for organizational innovation was the improvement of staff's skills with the improvement of suppliers' performance coming second and the changes on organizational structure coming third. New quality systems, technological upgrading, new methods of product delivery, new techniques and new processes of production were indicated as the most important process innovation outcome.

The strategic role of directors is reflected on focus and planning based on customer's needs and the introduction of appropriate processes of planning and control.

Additionally results illustrate that internal environment is enforced by focusing (i) on the staff's contribution, team work, and clear identification of operational aims, (ii) on the degree of liberty to act and risk taking freedom given to staff to define and execute their duties and (iii) on seriously emphasizing on awards and rewards which is the way successes and failures are dealt with and are rewarded constructing an autonomous and flexible organizational structure.

As to the causes hindering innovation, excessively high cost, lack of specialized personnel, legislation and lack of opportunities for development of technology suggest that an internal focused enterprise may be the most important inhibiting factor.

As to the causes hindering innovation process in the Cypriot Manufacturing Industry (sector of foods and beverage) are measured by examination of:

- Economic inhibitors parameters

- Organizational inhibitors parameters

- Other inhibitors parameters

As to the factors hindering the innovation process related to economic inhibitors the excessively high cost and the long period of depreciation were the most important inhibiting factors, followed by the non existence of suitable funding sources and the high risk surrounding innovation process.

The results of this study show the impact of innovative activities on organizational performance and especially on delivery times and the ability of the companies to satisfy customer needs.

Results from the factor analysis identify five important factors contributing to the level of innovativeness of the firms to be:

- the level of existence of Strategic Management Practices and Decisions, the level of Operational relations,

- Company strategy and capacity utilisation related to final goals,

- the level of Organizational reaction exterior environment influence,

- the level of Organizational and Structural orientation

- the level of the dynamism of internal structure and the capability of the production process.

\section{REFERENCES}

[1] T. Varzakas, and D.J. Jukes, “ The Globalisation of Food Regulation and Market Quality: A study of the Greek food market", In R.J. Loader, S.J. Henson, and W.B. Traill, (Eds), Globalisation of the Food Industry: Policy implications, The University of Reading, Reading, 1997.

[2] I.D. Boudouropoulos, and I.S. Arvanitoyannis, "Potential and Perspectives for applications of environmental management system (EMS) and ISO 14000 to food industries", Food Rev. Int., Vol. 16 , No. 2, pp. 117-237, 2000.

[3] J.P. Hoogland, A. Jellema, and W.M.F. Jongen, "Quality assurance systems, in Innovation of Food Production Systems: Product Quality and Consumer Acceptance", Waningen Pers, Waningen, pp. 139-58, 1998.

[4] M. Terziovski, "Achieving performance excellence through an integrated strategy of radical innovation and continuous improvement", Measur Bus Excellence, Vol. 6, No.2, pp. 5-14, 2002.

[5] M.A. Hitt, R.E. Hoskisson, R.A. Johnson, and D.D. Moesel, "A market for corporate control and firm innovation", Acad. Manag. J., Vol. 39, pp. 1084-1119, 1996.

[6] R. Rothwell, "Innovation and firm size: a case for dynamic complimentarily; or, is small really so beautiful?," J. Gen. Manag., Vol. 8, pp. 6-25, 1983.

[7] S.F. Cohn, and R.M. Turyn, "The structure of the firm and the adoption of process innovations", IEEE Trans. Eng. Manag., Vol. 27, pp. 98-102, 1980. 
[8] Australian Manufacturing Council, "Leading the way: A study of best manufacturing practices in Australia and New Zealand", Melburne, pp. 59-63, 1995.

[9] J.L.L. Francisco, A.R. Montes Moreno, and L.M. Molina, "An analysis of the relationship between quality and perceived innovation: The case of financial firms", Ind. Manag. Data Syst., Vol. 103, No 8, pp. 579-590, 2003.

[10] R.B. Tucker, "Innovation: the new core competency", Strategy Leaders, Vol. 29, No.1, pp. 11-14, 2001.

[11] A. Nelly, R. Filippini, C. Forza, and J. Hii, "A framework for analyzing business performance, firm innovation and related contextual factors: perceptions of managers and policy makers in two European regions", Integr. Manufact. Sys., Vol. 12, No. 2, pp.114124, 2001.

[12] M.E. Porter, "Competitive Advantage: Creating and sustaining superior performance", The Free Press, New York, NY, 1985.

[13] T.G. Guun, "Manufacturing for competitive advantage: becoming a world class manufacturer", Ballinger, Cambridge, MA, 1987.
[14] J.P. Womack, D.T. Jones, and D. Ross, "The machine that Changed the world", Rawson Associates, New York, NY, 1990.

[15] M. Zairi, "Benchmarking innovation best practice", World Class Des. Manufact., Vol. 2, No.3, pp. 33-40, 1995.

[16] R.J. Schonberger, "World Class Manufacturing", The Free Press, New York, NY, 1986.

[17] A. Efstathiades, S. Tassou, and A. Antoniou, "Strategic planning, transfer and implementation of Advanced Manufacturing Technologies (AMT). Development of an integrated process plan", Pergamon, 2002.

[18] B.B. Flynn, S. Sakakibara, and R.G. Schroeder, "The Interrelationship between JIT and TQM: practice and performance", Acad. Manag. J., Vol. 39, 1996.

[19] G.J. Avlonitis, A.G. Kouremenos, and N. Tzokas, "Assessing the Innovativeness of Organizations and its Antecedents: Project Innovstrat," Eur. J. Market., Vol. 28, No. 11, 1994.

[20] J. Hair, R. Anderson, R. Tatham, and W. Black, "Multivariate data analysis", $5^{\text {th }}$ ed. Upper Saddle River: Prentice Hall, 1998.

(C) Efstathiades et al.; Licensee Bentham Open.

This is an open access article distributed under the terms of the Creative Commons Attribution License (http://creativecommons.org/licenses/by/2.5/), which permits unrestrictive use, distribution, and reproduction in any medium, provided the original work is properly cited. 